\title{
Teaching Lean Principles through Simulation Games
}

\section{Dr. Faisal Aqlan, Penn State Behrend}

Dr. Faisal Aqlan is an assistant professor of industrial engineering at Penn State Behrend. He earned the B.S. and M.S. in industrial engineering from Jordan University of Science and Technology in 2007 and 2010, respectively and the Ph.D. in Industrial and Systems Engineering from the State University of New York at Binghamton in 2013. Prior to joining the faculty at Behrend, Dr. Aqlan was a faculty member in industrial and system engineering at the University of New Haven where he taught undergraduate and graduate courses. Dr. Aqlan has also worked on industry projects with Innovation Associates Company and IBM Corporation. His work has resulted in both business value and intellectual property. He has published several papers in reputed journals and conferences. Dr. Aqlan is a senior member of the Institute of Industrial and Systems Engineers (IISE) and has received numerous awards and honors including the IBM Vice President award for innovation excellence.

\section{Dr. E. George Walters III P.E., Penn State Behrend}

Dr. George Walters is an associate professor of Electrical and Computer Engineering at Penn State Erie, The Behrend College. He earned a B.S. in Electrical Engineering Technology from Penn State Harrisburg, an M.S. in Electrical Engineering and a Ph.D. in Computer Engineering, both from Lehigh University. He has been a licensed Professional Engineer in Pennsylvania since 1998.

Dr. Walters worked in industry as a controls and automation engineer for eighteen years prior to joining the faculty at Behrend in 2010. Most of his experience is in the design, development, and commissioning of PLC-based control systems for the food \& beverage and cement industries. He has developed and teaches a course on PLC-based control systems for engineers. He also teaches a course on advanced digital design using FPGAs, a course on embedded systems using 8- and 32-bit microcontrollers, and the two-semester capstone project sequence for electrical and computer engineers at Behrend. 


\title{
Teaching Lean Principles through Simulation Games
}

\begin{abstract}
In recent years, several training simulation games have been developed by academic and industry experts to support the teaching and learning activities of Lean philosophy. Using simulation games to teach Lean philosophy is an effective tool to convey the concepts to students. This paper discusses the teaching of Lean manufacturing principles to high school and undergraduate students through hands-on simulation experiments. Several Lean workshops and simulation games are offered to the students. Lean workshops aim to teach students the basics of Lean manufacturing as well as different Lean tools and techniques. Lean factory simulations include a set of hands-on experiments to teach students about manufacturing systems and Lean process improvement. In addition, Lean projects are implemented by undergraduate students in partnership with local industry. For each Lean activity, qualitative and quantitative data are collected and analyzed to assess the outcomes of the simulations, projects, and workshops.
\end{abstract}

\section{Introduction}

Lean manufacturing is a continuous improvement approach that focuses on elimination of nonvalue added activities. The concept of Lean manufacturing was originated at Toyota Motor Company. According to John Shook, Toyota's first (and still only) American manager in Japan, Lean manufacturing is defined as "a manufacturing philosophy that shortens the time line between the customer order and the shipment by eliminating waste"1. There are eight types of Lean wastes: defects, over-production, waiting, non-utilized talent, transportation, inventory, motion, and extra-processing. The first letters of these eight wastes can be summarized in the word DOWNTIME. Table 1 shows the eight Lean wastes and their description.

Table 1. Eight Lean wastes

\begin{tabular}{|l|l|}
\hline Lean Waste & Description \\
\hline Defects & Products to be reworked or scrapped \\
\hline Over-production & Producing more or earlier than required \\
\hline Waiting & Any non-work time waiting for tools, supplies, parts, etc. \\
\hline Non-utilized talent & Not using or being aware of people's talent \\
\hline Transportation & Unnecessary movements of products and materials \\
\hline Inventory & Excess products or material not being processed \\
\hline Motion & Unnecessary movements by people \\
\hline Extra-processing & More work or higher quality than is required by customer \\
\hline
\end{tabular}

Activities can be divided into three types: value added, non-value added, and non-value added essential ${ }^{4}$. A description of these is given in Table 2. Process improvement projects should focus on emphasizing value added activities, minimizing essential non-value added activities, and eliminating non-value added activities. Reducing the amount of non-value add activities reduces the production cost ${ }^{2}$.

When waste in a process is reduced using Lean manufacturing, cost eventually will be dropped, since the process takes less time to produce the same or more. In other words, the process 
becomes more efficient. This helps the company to maintain competitiveness over other companies in the market. Lean manufacturing also improves efficiency through reducing inventory, implementing a pull system and cellular manufacturing, reducing setup time, and by increasing process flexibility ${ }^{3}$. This can be achieved by utilizing Lean tools and techniques.

Table 2. Three main types of activities

\begin{tabular}{|c|c|c|}
\hline Activity Type & Description & Action \\
\hline Value Added & $\begin{array}{ll}\circ & \text { Adds value to product or service } \\
\circ & \text { It is done right the first time } \\
\circ & \text { Customer wants it }\end{array}$ & Emphasize \\
\hline $\begin{array}{l}\text { Non-value Added } \\
\text { Essential }\end{array}$ & $\begin{array}{l}\text { Does not add value to product or service and is necessary } \\
\text { for the delivery of product or service }\end{array}$ & Minimize \\
\hline Non-value Added & $\begin{array}{l}\text { Does not add value to product or service and can be } \\
\text { totally eliminated }\end{array}$ & Eliminate \\
\hline
\end{tabular}

\section{Lean Simulation Games}

Several training simulation games have recently been developed by academic and industry experts to support the teaching and learning activities of Lean philosophy. Using simulation games to teach Lean philosophy is an effective tool to convey the concepts to students. Moreover, simulation games can effectively be used to teach the soft and hard skills for successful Lean process improvement. A review study on simulation and games for teaching Lean manufacturing found that $75 \%$ of the Lean simulations and games focus on production lines. Other focus of the Lean simulations and games include enterprise-wide operations and non-manufacturing industry ${ }^{5}$. Table 3 shows some examples of Lean simulations and games ${ }^{5}$.

Table 3. Examples of Lean simulations and games

\begin{tabular}{|l|l|l|}
\hline Name of Simulation/Game & Focus & Product \\
\hline UK Paper Clip Simulation & Manufacturing & Paper Folders \\
\hline Buckingham Lean Game & Supply Chain & NA \\
\hline Lean Enterprise Value Simulation & Enterprise & Lego Aircraft \\
\hline Lean Product Development Simulation & Product Development & K'nex Product \\
\hline 5S Mini-Factory Simulation & Manufacturing & Tabletop Mini Factories \\
\hline Furniture Factory Simulation & Manufacturing & Wooden Furniture \\
\hline Ship Repair Design Process Simulation & Design Process & Container Ship \\
\hline Value Stream Mapping Board Game & Manufacturing & Board Game \\
\hline Lean Lego Simulation & Manufacturing & Lego Cars \\
\hline
\end{tabular}

\section{Teaching Lean to High School and Undergraduate Students}

At Penn State Behrend, Lean manufacturing workshops and simulation games are being offered to both high school students and undergraduate students. The objective of these workshops and simulation games is to provide the students with a practical understanding of Lean principles and process improvement methodologies. Several activities have been conducted over the last two years including workshops, simulation games, and practical projects with local industry. Table 4 summarizes the different types of Lean activities and their descriptions. 
Table 4. Lean activities and their descriptions

\begin{tabular}{|l|l|l|l|}
\hline Activity Name & Activity Type & Activity Description & Target Group \\
\hline $\begin{array}{l}\text { Explorers } \\
\text { Event }\end{array}$ & Workshop & $\begin{array}{l}\text { Provides career exploration opportunities } \\
\text { for young people aged 14 and up. }\end{array}$ & $\begin{array}{l}\text { High School } \\
\text { Students }\end{array}$ \\
\hline Lean 101 & Workshop & $\begin{array}{l}\text { Teaches Lean concepts and tools to } \\
\text { undergraduate engineering students }\end{array}$ & $\begin{array}{l}\text { Undergraduate } \\
\text { Engineering } \\
\text { Students }\end{array}$ \\
\hline $\begin{array}{l}\text { Lean Factory } \\
\text { Simulation }\end{array}$ & $\begin{array}{l}\text { Simulation } \\
\text { Game }\end{array}$ & $\begin{array}{l}\text { Teaches Lean manufacturing to } \\
\text { undergraduate by }\end{array}$ & $\begin{array}{l}\text { Undergraduate } \\
\text { IE Students }\end{array}$ \\
\hline 5S Simulation & $\begin{array}{l}\text { Simulation } \\
\text { Game }\end{array}$ & $\begin{array}{l}\text { Teaches 5S methodology to } \\
\text { undergraduate students by }\end{array}$ & $\begin{array}{l}\text { Undergraduate } \\
\text { IE Students }\end{array}$ \\
\hline $\begin{array}{l}\text { Lean Project in } \\
\text { local industry }\end{array}$ & $\begin{array}{l}\text { Industry } \\
\text { Projects }\end{array}$ & $\begin{array}{l}\text { Apply Lean to solve real life problems in } \\
\text { a local company }\end{array}$ & $\begin{array}{l}\text { Undergraduate } \\
\text { IE Students }\end{array}$ \\
\hline
\end{tabular}

The Explorers Event is conducted every year in February and targets high school students. The event involves teaching the high school students Lean manufacturing concepts and it includes lectures and in-class activities. Students are also given tours to the different laboratories and participate in other laboratory experiments conducted on different topics including 3D printing, laser welding, etc. Figure 1 shows pictures from a recent Explorers Event.

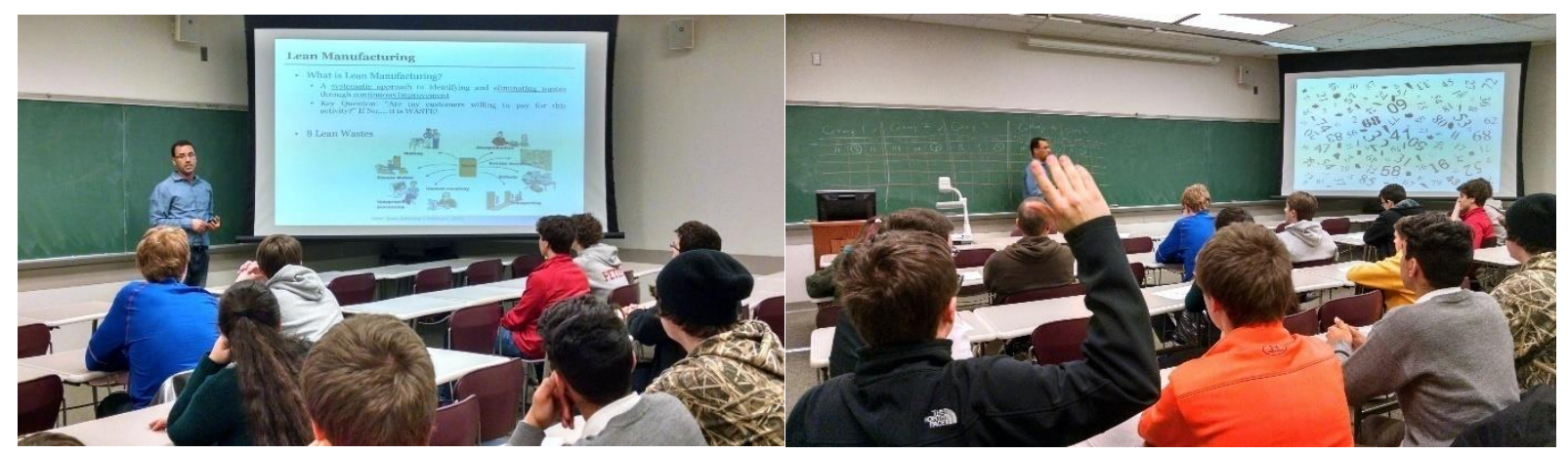

Figure 1. Lean number games workshop for high school students

The Lean 101 workshop is a 3-hour course offered to all Engineering students who are interested in learning Lean manufacturing. The workshop is offered by the Institute of Industrial and Systems Engineers (IISE) Chapter at Penn State Behrend. The workshop is offered in the Spring and Fall semesters. Most of the students who attend the workshop get internship positions and apply what they learn at the workshop in their internships. A survey was developed to gather student feedback (if they already participated) and interest (if they have not) about the workshop. Student feedback on the workshop has been collected and analyzed. A sample survey is shown in Table 5, and survey results of the first seven questions are shown in Figure 2. The survey was distributed to 35 senior and junior students and 30 responses were received. From Figure 2, it is noted that most students agree that workshop was effective and helped them to understand the Lean concepts. 
Table 5. Sample survey for the Lean 101 survey

\begin{tabular}{|c|l|lllll|}
\hline No. & Question & Answer & \\
\hline Q1 & $\begin{array}{l}\text { The workshop helped me understand the Lean manufacturing } \\
\text { concepts and techniques. }\end{array}$ & 4 & 3 & 2 & 1 & NA \\
\hline Q2 & Information and/or skills presented were relevant and useful. & 4 & 3 & 2 & 1 & NA \\
\hline Q3 & The materials provided were useful. & 4 & 3 & 2 & 1 & NA \\
\hline Q4 & I can now apply Lean to real life process improvement cases. & 4 & 3 & 2 & 1 & NA \\
\hline Q5 & The hands-on activities were useful and effectively taught. & 4 & 3 & 2 & 1 & NA \\
\hline Q6 & The videos were helpful and informative. & 4 & 3 & 2 & 1 & NA \\
\hline Q7 & Do you recommend this workshop to other students? & 4 & 3 & 2 & 1 & NA \\
\hline Q8 & $\begin{array}{l}\text { How would you rate the presenter's knowledge of the subject? } \\
\text { (please check one). }\end{array}$ & $\begin{array}{l}\square \text { Excellent } \square \text { Good } \\
\square \text { Fair } \square \text { Poor }\end{array}$ \\
\hline Q9 & How do you rate the overall quality of the presenter? & $\begin{array}{l}\square \text { Excellent } \square \text { Good } \\
\square \text { Fair } \square \text { Poor }\end{array}$ \\
\hline Q10 & How would you rate the overall quality of this workshop? & $\begin{array}{l}\square \text { Excellent } \square \text { Good } \\
\square \text { Fair } \square \text { Poor }\end{array}$ \\
\hline
\end{tabular}

4= Strongly Agree 3= Agree 2= Disagree 1= Strongly Disagree NA: Not Applicable

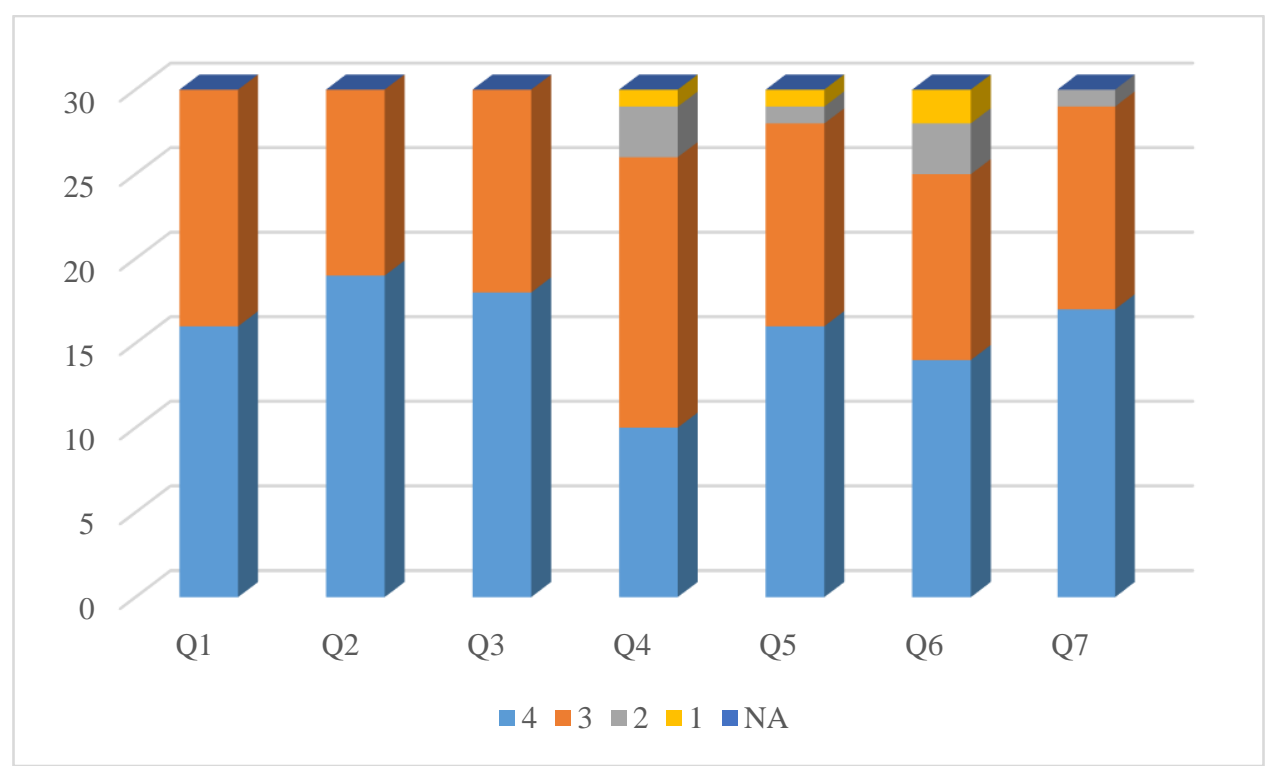

Figure 2. Survey results for Lean 101 workshop (questions 1-7)

For questions 8-10, most of the respondents rated the quality of the presenter and the course as excellent (see Figure 3). 


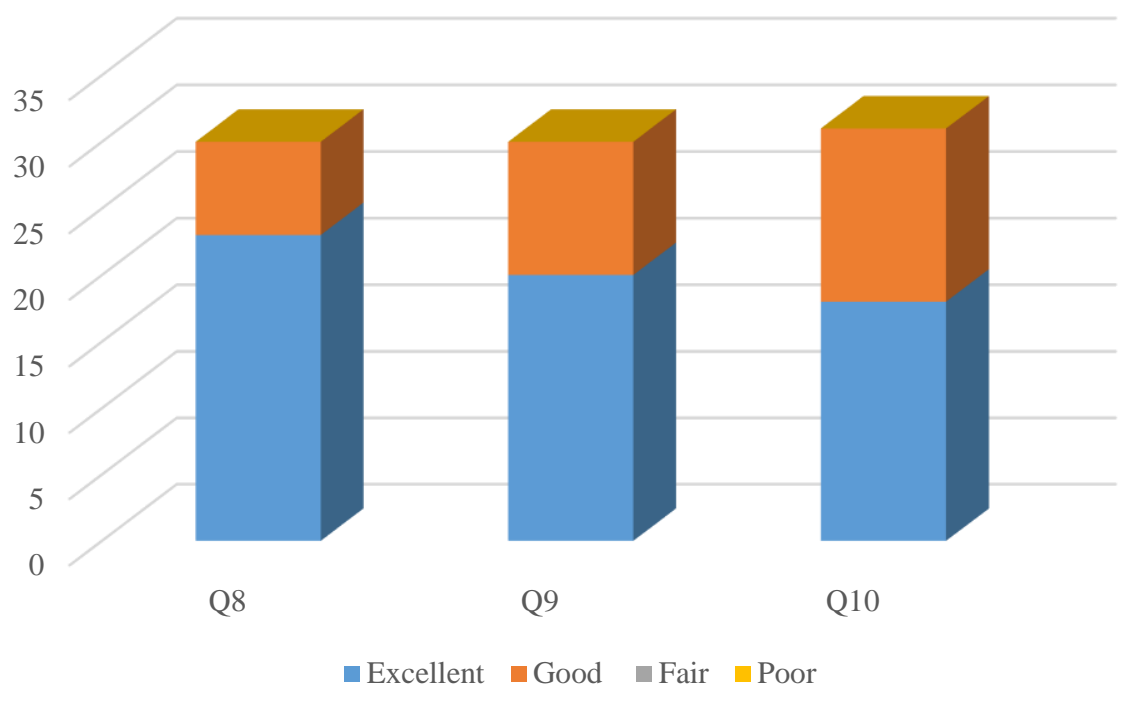

Figure 3. Survey results for Lean 101 workshop (questions 8-10)

Out of the 35 surveyed students who took the Lean 101 workshop, 19 indicated that they had an internship during the summer. Of those 19 students, 16 had their internship in a manufacturing environment, and 15 students had an internship related to Lean manufacturing and/or process improvement. Students who had an internship were asked to answer questions related to the workshop (see Table 6).

Table 6. Internship-related survey for the Lean 101 workshop

\begin{tabular}{|c|c|c|c|c|c|}
\hline Number & Question & Answer & & & \\
\hline Q1 & $\begin{array}{l}\text { The workshop was helpful and relevant to your } \\
\text { internship. }\end{array}$ & 43 & 2 & 1 & NA \\
\hline Q2 & $\begin{array}{l}\text { Has the workshop inspired you to seek out an } \\
\text { internship? }\end{array}$ & 43 & 2 & 1 & $\mathrm{NA}$ \\
\hline Q3 & The workshop helped me find an internship. & 4 & 2 & 1 & NA \\
\hline Q4 & $\begin{array}{l}\text { I anticipate career advancement as a result of } \\
\text { completing the internship. }\end{array}$ & 4 & 2 & 1 & NA \\
\hline Q5 & $\begin{array}{l}\text { I will prefer to get a job in Lean manufacturing } \\
\text { and/or process improvement. }\end{array}$ & 43 & 2 & 1 & NA \\
\hline
\end{tabular}

4= Strongly Agree 3= Agree 2= Disagree 1=Strongly Disagree NA: Not Applicable

The survey results of the internship questions are shown in Figure 4. Most students think that the workshop was helpful and relevant to their internships. Some students, however, have an internship that is not related to process improvement and they don't agree that the workshop was relevant to their internship. For question 2, most students who had no internships indicated that the workshop inspired them to seek one, while many students who already had internships answered the question with "Disagree or Strongly Disagree". Students also did not agree that the workshop helped them to find an internship, especially those who already had one. However, 
students prefer to find a job in Lean manufacturing and/or process improvement after they learned about these topics in the workshop.

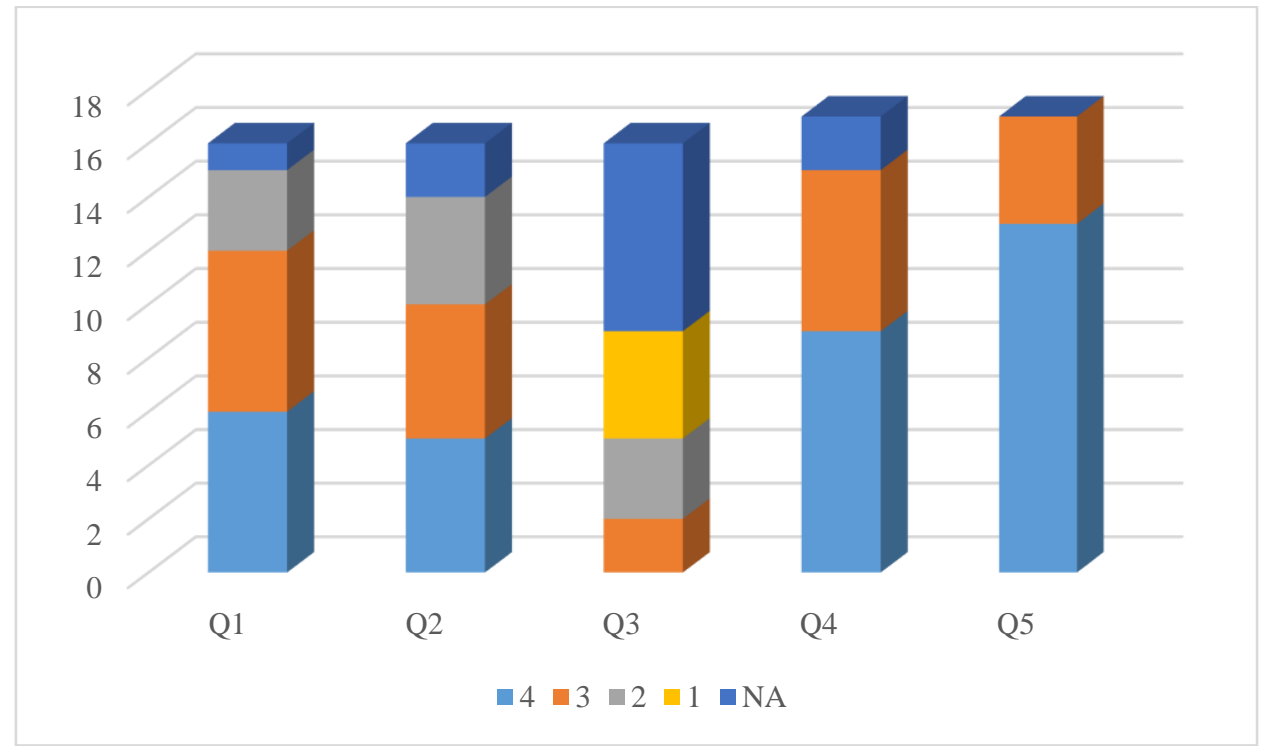

Figure 4. Survey results for questions related to internships

The last part of the survey includes 5 qualitative questions to gather student feedback on the workshop. The five qualitative questions are:

Q1: What skills did you learn that may help prepare you for working in industry?

Q2: What did you like best or find most useful about the workshop?

Q3: Things you did not like about the workshop.

Q4: Suggestions for improving the workshop.

Q5: Areas/topics about which you would like to receive further training.

Students' answers to the five questions, which are qualitative statements, were analyzed using word clustering as shown in Figure 5. For question 1, students' responses indicate that the skills they learned are Lean, Lean thinking, and Lean waste elimination. Responses to the second question indicate that students like the Lean activities and videos. However, some students think that the videos were long as indicated by the responses to question 3. Suggestions for improvement include shortening the workshop or including short breaks and having more activities during the workshop. It should be noted that all the classes that the students are taking are only 50 minutes and the workshop is the first 3-hour long lecture they attend. This may explain why the students think the workshop was long. Students also would like to receive more workshops on Six Sigma as indicated by their response to question 5.

The factory simulation experiments are designed to teach students the basics of manufacturing systems. Four simulation experiments were conducted: Batch and Queue production, Cellular Flow Push production, Cellular Flow Pull production, and Lean Flow production. The layouts of the Batch and Queue and the Lean Flow Productions experiments are shown in Figures 6 and 7, respectively. Table 7 shows sample results of the car factory simulations. It can be seen that the Lean Flow has the highest values for profit and production rate. Simulation time was set to 10 minutes. 


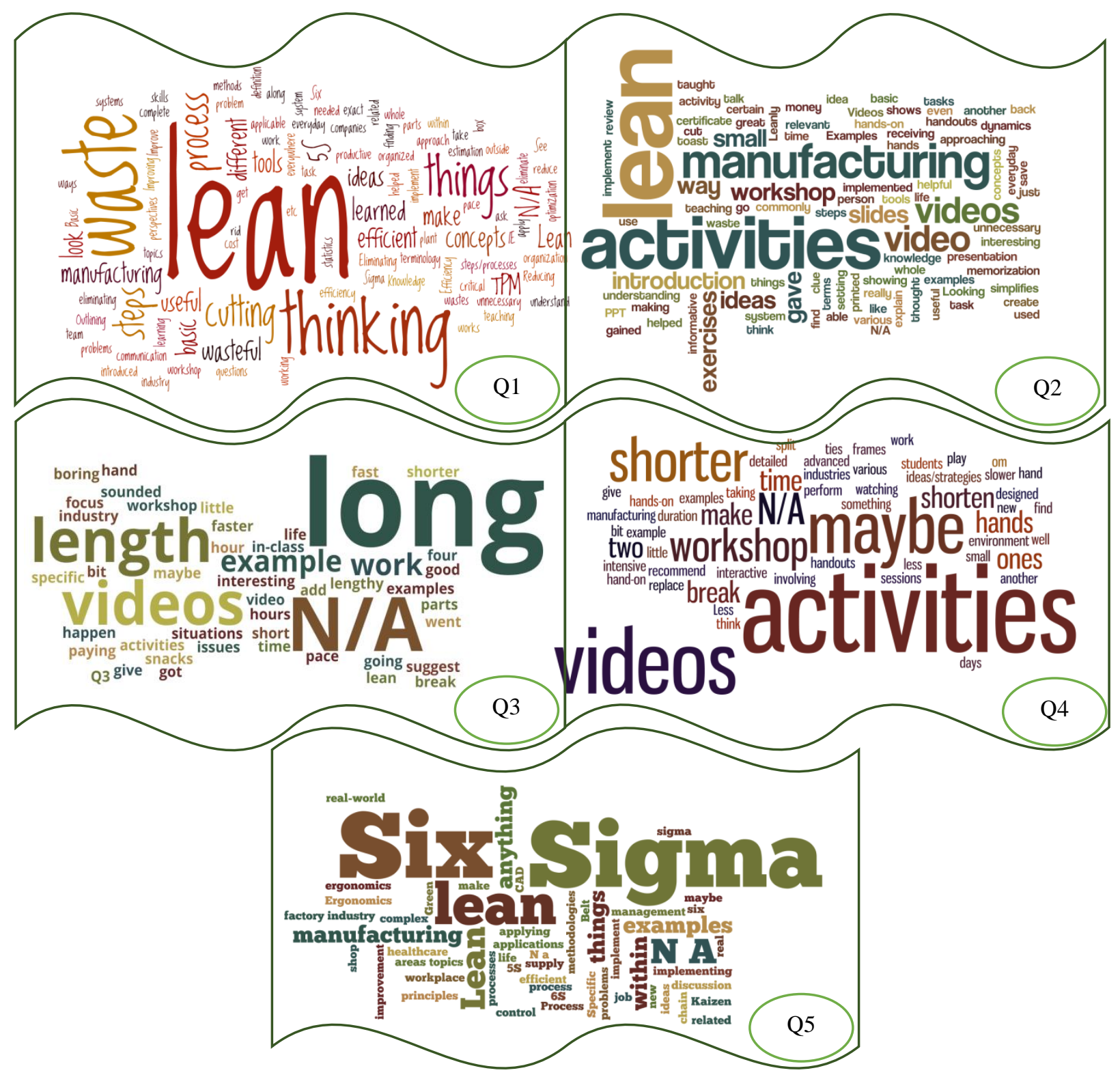

Figure 5. Word clustering for qualitative survey questions

Table 7. Sample results of the car factory simulations

\begin{tabular}{|c|c|c|c|c|c|c|c|c|c|}
\hline \multirow{2}{*}{ Cost Item } & \multirow{2}{*}{ Simulation Experiment } & \multicolumn{2}{|c|}{ Batch and Queue } & \multicolumn{2}{|c|}{ Cellular Flow Push } & \multicolumn{2}{|c|}{ Cellular Flow Pull } & \multicolumn{2}{|c|}{ Lean Flow } \\
\hline & & Number & $\$$ & Number & $\$$ & Number & $\$$ & Number & $\$$ \\
\hline Revenue & Sales $(\$ 500 /$ car $)$ & 18 & 9,000 & 24 & 12,000 & 26 & 13,000 & 29 & 14,500 \\
\hline \multicolumn{2}{|c|}{ Total Sales } & \multicolumn{2}{|c|}{$\$ 9,000$} & \multicolumn{2}{|c|}{$\$ 12,000$} & \multicolumn{2}{|c|}{$\$ 13,000$} & \multicolumn{2}{|c|}{$\$ 14,500$} \\
\hline \multirow{5}{*}{ Costs of Goods Sold } & Raw Material (\$100/car) & 18 & 1,800 & 24 & 2,400 & 26 & 2,600 & 29 & 2,900 \\
\hline & Labor (\$165/worker) & 6 & 990 & 6 & 990 & 6 & 990 & 3 & 495 \\
\hline & Overtime (\$40/minute) & 0.65 & 25.6 & 0 & 0 & 0 & 0 & 0 & 0 \\
\hline & Overhead (\$10/chair) & 5 & 50 & 6 & 60 & 5 & 50 & 3 & 30 \\
\hline & Scrap $(\$ 100 /$ car $)$ & 0 & 0 & 0 & 0 & 0 & 0 & 0 & 0 \\
\hline \multicolumn{2}{|c|}{ Total Cost of Goods Sold } & \multicolumn{2}{|c|}{$\$ 2,865.6$} & \multicolumn{2}{|c|}{$\$ 3,450$} & \multicolumn{2}{|c|}{$\$ 3,640$} & \multicolumn{2}{|c|}{$\$ 3,425$} \\
\hline \multirow{3}{*}{ Capital Charge } & $\mathrm{WIP}(\$ 60 / \mathrm{car})$ & 0 & 0 & 0 & 0 & 0 & 0 & 1 & 60 \\
\hline & Facilities (\$15/Table) & 6 & 90 & 3 & 45 & 6 & 90 & 2 & 30 \\
\hline & Facilities (\$10/Fixture) & 5 & 50 & 2 & 20 & 3 & 30 & 0 & 0 \\
\hline \multicolumn{2}{|c|}{ Total Capital Charge } & \multicolumn{2}{|c|}{$\$ 140$} & \multicolumn{2}{|c|}{$\$ 65$} & \multicolumn{2}{|c|}{$\$ 120$} & \multicolumn{2}{|c|}{$\$ 90$} \\
\hline \multicolumn{2}{|c|}{ Sales - Costs of Goods Sold - Capital Charges } & \multicolumn{2}{|c|}{$\$ 5,994.4$} & \multicolumn{2}{|c|}{$\$ 8,485$} & \multicolumn{2}{|c|}{$\$ 9,240$} & \multicolumn{2}{|c|}{$\$ 10,985$} \\
\hline \multicolumn{2}{|c|}{ Production Rate (car/minute) } & \multicolumn{2}{|c|}{1.69} & \multicolumn{2}{|c|}{2.40} & \multicolumn{2}{|c|}{2.60} & \multicolumn{2}{|c|}{2.90} \\
\hline
\end{tabular}




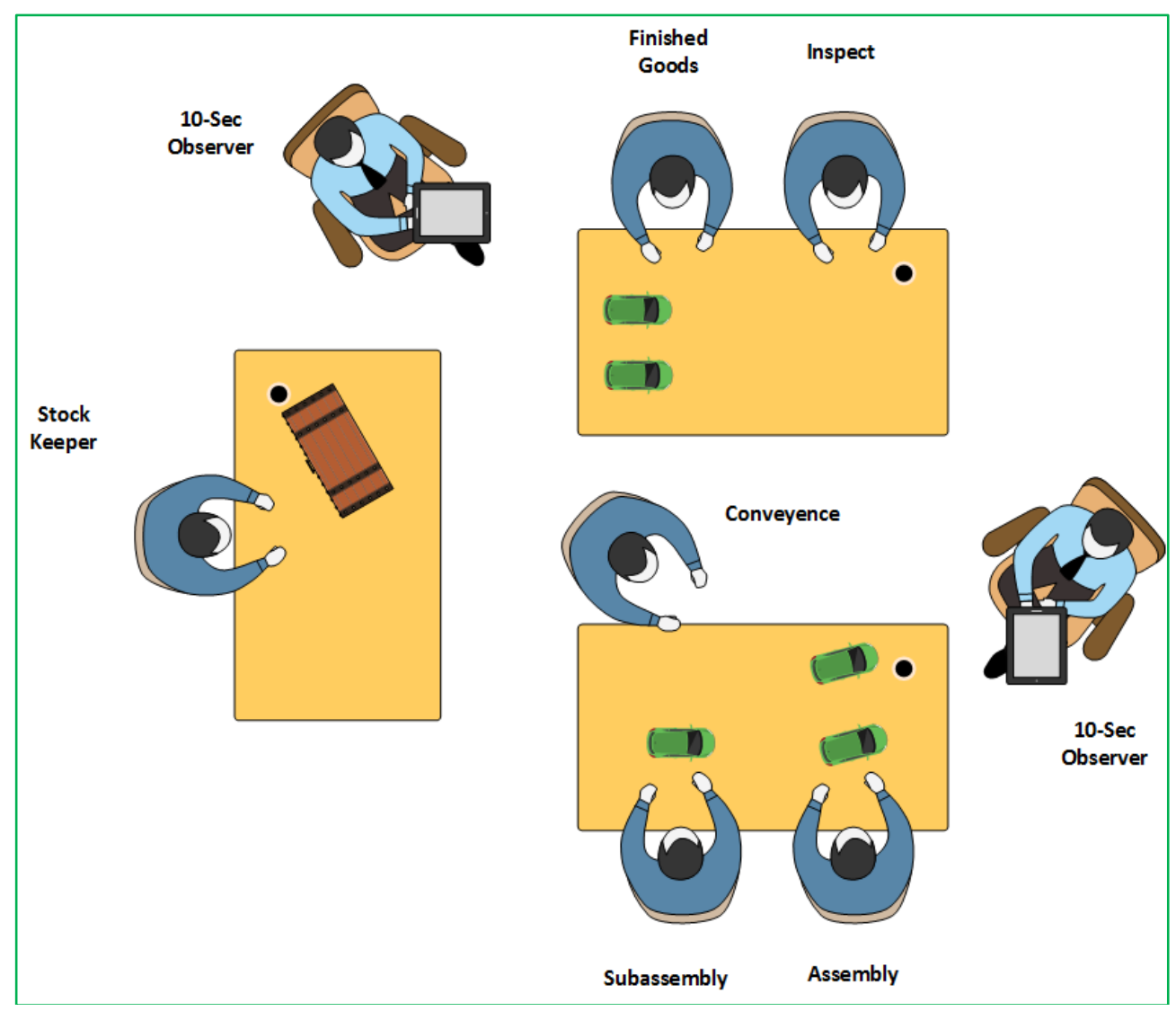

Figure 6. Factory layout for batch production simulation

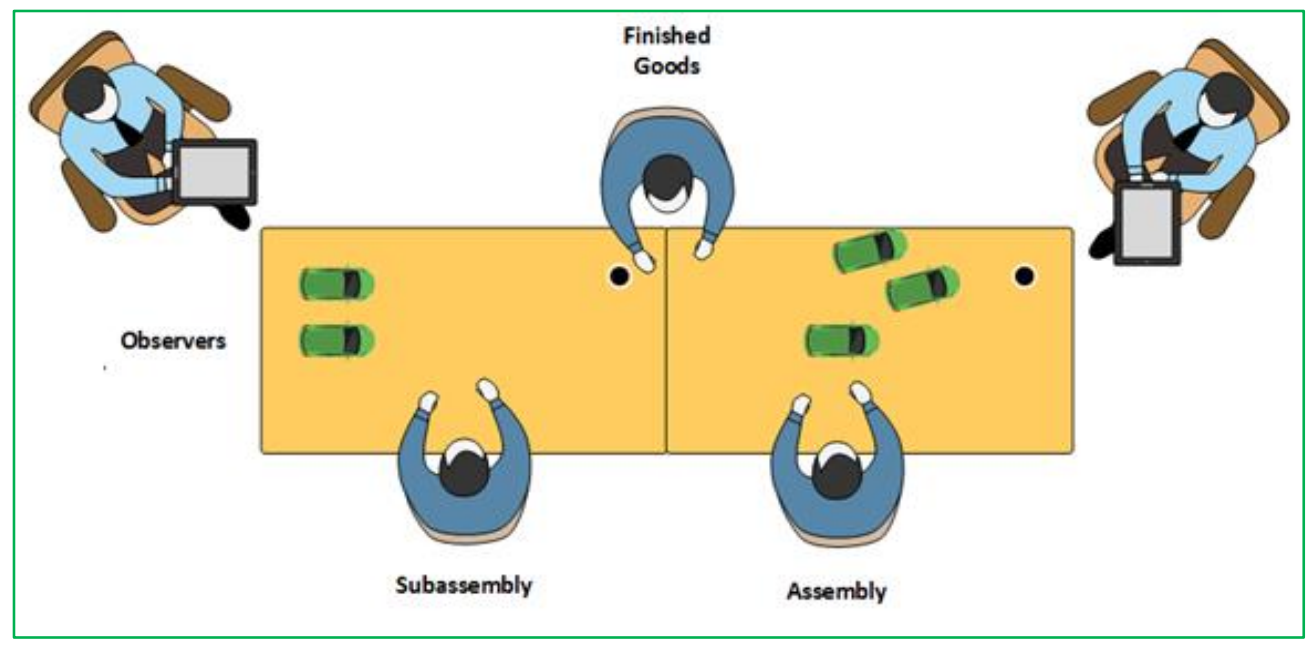

Figure 7. Factory layout for Lean production simulation 
The 5S simulation experiment involves two activities, Before and After, where students are asked to assemble a product. The Before activity, shown in Figure 8, involves students performing an assembly of a plane where the parts and tools are randomly placed on the tables. Students were given two hours to finish the activity and they spent the first 40 minutes trying to find the tools and parts used in the assembly process.

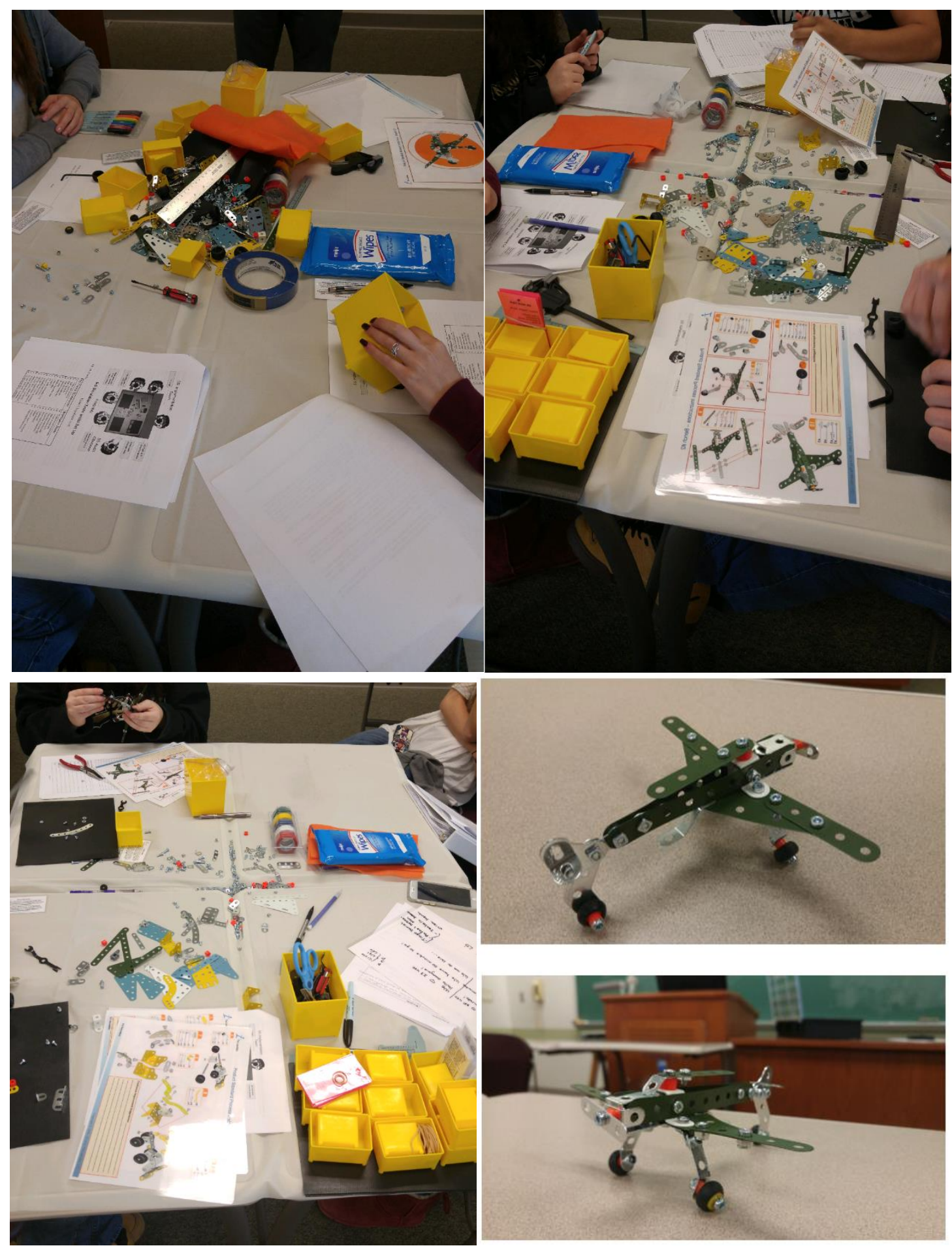

Figure 8. Lean simulation game for 5S methodology (Before) 
In the After activity, students implemented $5 \mathrm{~S}$ to remove the parts and tools they don't need and reorganize the workplace as shown in Figure 9. Students were able to complete the process with $50 \%$ less time.
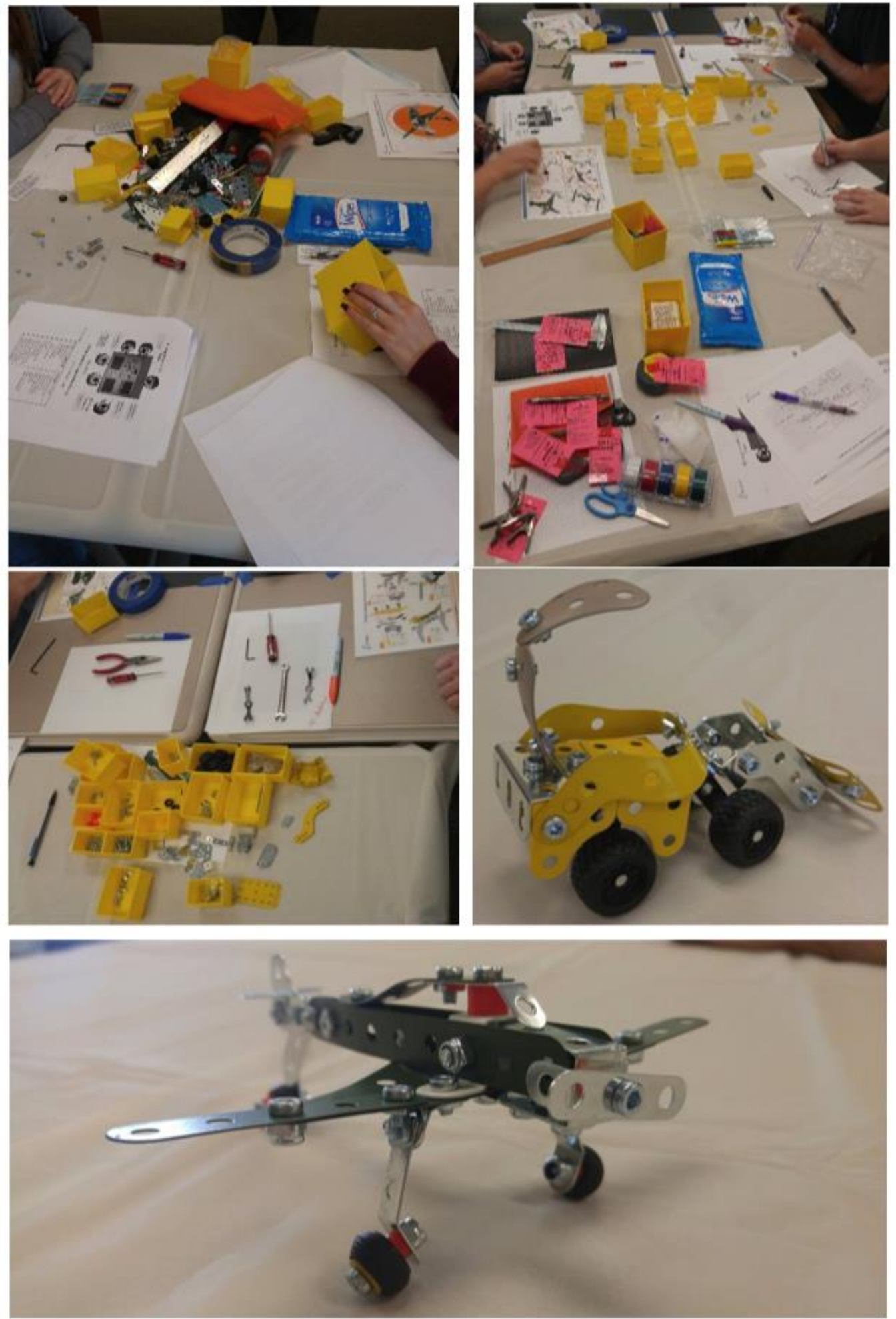

Figure 9. Lean simulation game for 5S methodology (After) 
Lean process improvement projects with local industry aim to provide students with hands-on experience applying what they have learned in class to real life situations. The process improvement projects were implemented at a company in the casting industry. Five different projects were selected and teams of four students were assigned to work on each project. After assigning the teams to the selected projects, each team worked on collecting data on the specific problem and developed a clear problem statement and project objectives. Process improvement and Lean tools and techniques were used in the projects.

Students used the concepts, tools, and techniques they learned through simulation games as well as course lectures to solve the assigned problems. After completing the projects, students were asked to provide their overall feedback on the industry project. Figure 10 shows the Word Clustering for the student feedback. The most frequent words are "hands-on", "experience", "Lean", "think", "semester", "time" "beginning". From these words, we can conclude that the students "gained real life hands-on experience by implementing real-life projects which helped them think Lean". Students also suggest that the selection and assignment of the projects should be in the beginning of the semester because they think more time was needed to complete the projects. This is because the projects were assigned in the third week of the semester due to logistics required to obtain the projects as well as develop the project plans and form the teams. In addition, the course instructor along with the industry partner needed to identify several projects and select the ones that fit the course content and benefit both the students and the company.

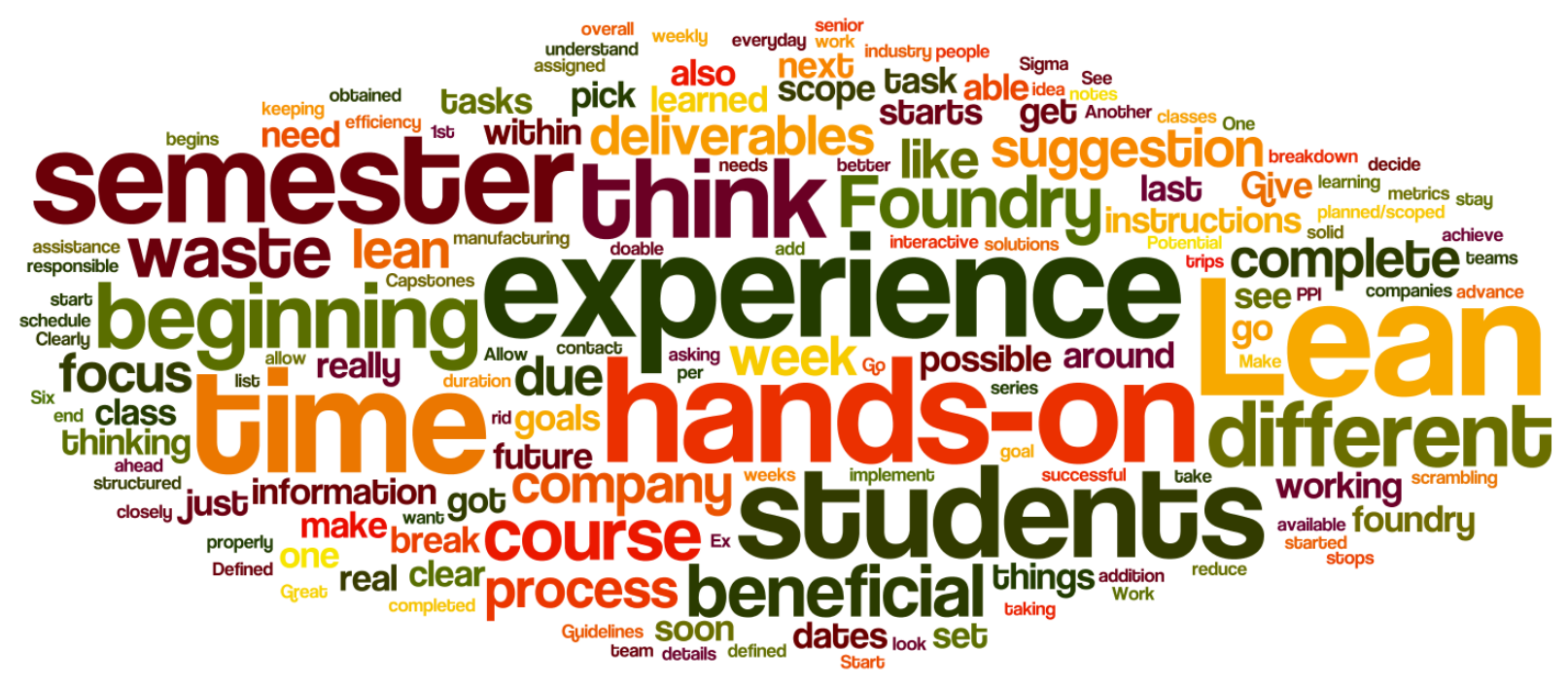

Figure 10. Word clustering for student feedback on the industry project

\section{Conclusions}

In this study, we present several examples of teaching Lean manufacturing concepts through simulation games and real life industry projects. Qualitative and quantitative data were collected and analyzed to measure the learning outcomes. Student feedback indicates that the simulation activities are effective ways for understanding Lean concepts. Furthermore, the Lean manufacturing projects allow students to gain hands-on experience and apply what they learn to real life situations. 
One of the main factors that the current Lean simulations and games do not consider is the cognitive skills and cultural aspects which are important for Lean manufacturing sustainability. In future work, we plan to integrate the cognitive and cultural factors into the Lean simulation games. This will also require the development of assessment measures for the learning outcomes.

\section{References}

1. Liker, J.K., (1997) 'Becoming Lean: Inside stories of U.S. manufacturers', CRC Press.

2. Tandon, P., Tiwari, A., Tamrakar, S., (2014) 'Implementation of Lean manufacturing principles in foundries', International Journal of Modern Engineering Research, Vol. 4, No. 2., pp.1-5.

3. Klier, T., (1993) 'Lean manufacturing: understanding a new manufacturing system', Chicago Field Letter, March, Vol. 67, pp.1-4, ABI/INFORM Global.

4. Aqlan, F., Ashour, O., and Pedersen, A., (2016) 'Lean process improvement of first case scheduling in operating rooms', Proceedings of the 2016 International Conference on Industrial Engineering and Operations Management, Detroit, MI, pp. 707-716.

5. Badurdeen, F., Marksberry, P., Hall, A., and Gregorry, B., (2010) 'Teaching Lean manufacturing with simulations and games: A survey and future directions', Simulations and Gaming, Vol. 41, No. 4, pp. 465-486. 